\title{
The Impact of Governance on Economic Growth and Human Development During Crisis in Middle East and North Africa
}

\author{
Eman Hashem ${ }^{1}$ \\ ${ }^{1}$ Associate professor of Economics-faculty of commerce, Ain Shams University, Egypt \\ Correspondence: Eman Hashem, Associate professor of Economics-faculty of commerce, Ain Shams University, \\ Egypt. E-mail: emyhashem2004@yahoo.com
}

Received: June 3, 2019

Accepted: June 29, 2019

Online Published: July 8, 2019

doi:10.5539/ijef.v11n8p61

URL: https://doi.org/10.5539/ijef.v11n8p61

\begin{abstract}
The aim of this paper is to determine the impact of governance on economic growth and human development in MENA countries. And whether the financial crisis affects the relationship between governance and Economic growth.

So, this paper is based on data of 20 countries during the period (1996-2017) we used panel data (longitudinal data) which combines cross sectional data and time series data by applying the three longitudinal data model: pooled regression model, fixed effect model and random effect model.

This paper found that there is no relationship between governance and economic growth in MENA countries and no impact of the global financial crisis in 2008 on the relationship between governance and economic growth.

Also, the paper found that there is a significant relationship between governance and human development.
\end{abstract}

Keywords: governance, Economic growth, human development, MENA

\section{Introduction}

Since the end of 1980s, good governance has become an important topic in development, as it can be applied to a wide range of issues and relationships. In 2003, the World Bank issued a report entitled "Better governance for development in the Middle East and North Africa" stating (the issue of good governance is not political issue but a development issue because good governance has a main role in promoting economic development and in offering essential social services).

Good governance (credible voice \& accountability, political stability, an effective government, an efficient regulatory system, the rule of law and fighting corruption) can help in achieving a high level of economic growth through providing an attractive environment for investment and savings. Also, good governance can reduce the challenges that face international trade.

According to the World Bank's World Governance indicator, if we compare the governance of MENA region to other regions in the world, it ranks below the average. MENA scores average refers to that the region does not rank above the $50^{\text {th }}$ percentile in any of the 6 indicators of governance.

Poor governance can hinder economic growth and human development through political instability, ineffective rule of law and corruption.

The objectives of this paper are, first, we illustrate the main governance indicators in MENA and determine the main challenges facing good governance in MENA.

Second, investigate to what extent governance affect economic growth in MENA and whether financial crisis affect the relationship between governance and economic growth.

Third, investigate to what extent governance affect human development in MENA

\section{Literature Review}

There are a lot of studies that concentrates on the effect of governance on economic growth, but there are few studies that analyse the impact of economic crisis in this effect.

There is a common agreement in most studies about the existing of the relationship between governance and 
economic growth.

(Bichaka \& Christian, 2010) study that analyzes this effect by using time series data for the period (1995-2005) for 28 African countries. It found that there is a significant and positive relationship between good governance and economic growth.

(Mahmoud, 2012) this paper used panel data analysis to show to what extent MENA countries governance can be related to its economic growth and what is the impact on GDP growth to governance indicators.

The study showed the main dimensions of governance that the policymaker should concentrates on, as it has more effect on enhancing growth. This study found that government effectiveness and rule of law are affected per capita GDP growth more than other governance indicators.

(Engjell, 2015) study that analyzes the impact of good governance on the economic growth by using a panel data for western Balkan countries for the period (1996-2012).

The study found that some of the dimensions of good governance have the faster impact on economic growth than others, as political stability, absence of violence and the strengthening of law enforcement has the effect on economic growth at the same period, while governance accountability affects economic growth in future periods.

There are different thoughts about the impacts of crisis on the relationship between governance and Economic growth.

(Bassam, 2013), this paper examined the relationship between governance and growth during economic crisis and during non-crisis periods. The paper found that the existing of the relationships between economic growth and governance during crisis and non-crisis periods. The study found that the relationship are significant whether before or after the economic crisis in 2008.

It concluded that the level of development in a country is concerned with the effect of governance on economic growth during economic crisis.

This paper also concluded that the level of country development has an effect on the relationship between governance and growth during crisis. A country's level of development affects the shaping of the relationship between governance and growth during crisis.

(Hasan \& Erdogan, 2017) study that examines the effect of governance on economic growth during economic crisis through changing in institutional quality. It found that the economic crisis has an effect on the level of institutional quality and this has a positive impact on economic growth.

Countries that changed their bureaucratic organization, made better socioeconomic and investment environment after their economic crisis and that had a positive impact on enhancing economic growth.

The aim of this paper is to determine the impact of governance on economic growth and human development in MENA countries. And determine whether the financial crisis affect this relationship.

This paper is organized as follows, Section 3 illustrate the definition of governance. Section 4 discuss the relationship between Economic growth and the 6 components of governance also, discuss whether the crisis will affect this relationship. Section5 analyse governance status in MENA. Section 6 determines the main challenges facing governance improvement in MENA. Finally section 7 estimates the impact of governance on economic growth \& human development in MENA countries.

The methodology used in this paper to test the relationship between governance, Economic growth and human development based on panel data for 20 countries during the period (1996-2017) using Eviews 10 by applying the three longitudinal data models: pooled regression model, fixed effect model and random effect model.

And in order to determine the impact of the 2008 financial crisis on the relationship between governance, economic growth and human development the study period was divided into two periods (1996-2007) and (2008-2017).

\section{Governance and Good Governance}

Governance is a concept that includes all fields of the authority exercises by formal and informal institutions in the management of the available resources of the government. Governance quality is affected by the power exercise effect on the quality of life enjoyed by its citizens (Jeff Huther \& Anwar shah, 1998, p. 2).

Governance is the group of traditions and institutions that the authority in a country did. It consists of a) the governments' selection, monitoring and replacement process, b) the government ability of policies formulation and implementation and c) people and country respect to the institutions that is the governor of economic and 
social relations among them (Daniel, Aart, \& Massimo, 2010, p. 4).

Good governance is the development policies management and orientation that affect economic performance positively. Good governance according to World Bank defined as the management and institutional reforms that state did and develop coordination and important public services delivery, political responsible accountability and roles of citizens in the development policies (Rachid \& Ahmed, 2017, p. 109).

For the World Bank, good governance is assessed by the government elements capacity of a country application and putting a framework for market progress and economic development (Rachid \& Ahmed, 2017, p. 108).

World Governance Indicators are the most effective indicators in measuring governance that policy makers, international organizations and donors and agencies and investors used. World Governance Indicators contains 6 aspects: Voice and Accountability, political stability and violence absence, government effectiveness, regulatory quality, Rule of law and control of corruption.

The aggregate WGI has two measures: the standard normal units of the governance indicator which range from -2.5 to 2.5 (higher levels indicating greater improvement for good governance), and the percentile rank which range from 0 and 1 and if it becomes near 1, it means there are a lot of efforts for higher governance.

These indicators aims at measuring good governance evolution for a country and a policy application to enhance these indicators to ensure that enhancing good governance could lower the government failure.

\section{Governance and Economic Growth}

Effective governance in a country leads to achieving a high level of economic growth by having an attractive environment for investment and savings and by lowering the obstacles facing international trade (Adnen \& Mohamed, 2015, p. 28).

Good governance is an important prerequisite to enhance economic growth and development. Through enhancing environment for investment and facilitate the market to be efficiently. Good governance improves the development of private sector and market to reach higher growth.

\subsection{Economic Growth \& Voice and Accountability}

Voice and accountability measure the ability of country's citizens to become a part of government selection as well as expression, association and free media freedoms (Thomas, 2010, p. 32).

Voice and accountability is important dimension of governance. Voice indicates to the capacity to express opinions and interests and to the implementation of this, in order to affect government priorities and governance processes.

Accountability refers to that people who apply and implement the rules are answerable to citizens who lives are affected by those rules.

So, Voice and accountability is important indicator to determine the nature of the relationship between government and its citizens (Tammie, Marta, \& Alan, 2007, p. 1).

Voice and accountability concern with the progress of two causes; first, lack of power and accountability are the reasons of poverty. As, voice and accountability can lead to reduction in poverty by itself. Second, voice and accountability can cause other advantages as higher ownership and pro poor policies which can in turn reduce poverty rates (Tammie, Marta, \& Alan, 2007, p. 9).

\subsection{Economic Growth \& Political Stability}

Political instability affects economic growth negatively as political instability motivated violence and terrorism. (United Nation, 2007, p. 16).

The relationship between political stability and growth has two effects. First, uncertainty that caused from an unstable political system may lower private investment and so economic growth. Second, uncertainty may alter the sort of investment undertaken, or change the public spending composition and other factor demands and so affect economic growth directly (Dimirios \& Simon, 2001, p. 383).

In addition, poor economic performance may lead to government failure and political instability (Alesina, Alberto, Sule, Nouriel, \& Phillip, 1996, p. 190).

Internal and external conflicts can seriously lower growth by decreasing physical and human capital. Political conflicts lead to increasing defence expenditures significantly and so decreases spending on human capital (education \& health). Also, defence expenditures increasing can lower domestic investments which can decrease the economic growth of the economy (Emin \& Alpaslan, 2017, p. 366). 


\subsection{Economic growth \& Government Effectiveness}

It indicates to perception capturing of public services quality, civil service quality and its independence degree from political pressures, the quality of policy formulation and implementation, and the commitment of the government to such policies (Daniel, Aart, \& Massimo, 2010, p. 4).

Good governance causes higher economic growth, by enhancing more efficient labour divisions and faster social and economic policies implementation.

An efficient government can promote market and then leads to increasing private investment and economic growth, by increasing capital accumulation, putting resources in good sectors and learning new technologies to achieve economic growth (Md Rafayat, Erick, \& Bizuayehu, 2017, p. 223).

\subsection{Economic Growth \& Regulatory Quality}

It is a necessity for economic growth by making markets doing their jobs in an efficient way, so it provides a sound environment for private investment, and then enhancing economic growth.

It refers to the government ability to formulate and implement good policies and regulations that enhances private sector investment (Daniel, Aart, \& Massimo, 2010, p. 4).

Regulatory quality is necessary for economic growth by making market works in an efficient way, so it provides a sound environment for private investment, and then enhancing economic growth (Colin, 2014, p. 162).

\subsection{Economic Growth \& Rule of Law}

It refers to a society success in enhancing an environment in which sound rules and procedures from economic and social interactions are protected. It is a necessity for consolidating a fair market economy that increases economic growth.

The Rule of law consists of perceptions of the crime, the effectiveness of the Judiciary and the enforceability of contracts (Christiane \& Charles, 2006, p. 6).

Rule of law is an important condition for consolidating an accessible, fairer market economy that enhances economic growth and development.

A set of factors as the protection of individual property rights, putting labour laws, facilitating market creation and access for the poor and marginalized groups enhances economic growth (Louis \& Deval, 2013, p. 9).

\subsection{Economic Growth \& Control of Corruption}

Control of corruption refers to the control of which public power is used for private gains, which includes petty and grand sorts of corruption, and capturing the country by elites and private interest (Xuehul, Haider, \& Juzhong, 2014, p. 4).

Corruption affects a set of transmission channels, as investment (which includes FDI), entrepreneurship, competition, government efficiency. Besides that, corruption has an effect on other important indicators of economic growth as the environment quality, income distribution and personal health and safety status, which have a significant effect on economic welfare. (OECD, 2013, p. 1).

Corruption leads to decreasing FDI flows by lowering its profitability. Corruption causes a tax revenues decrease, as it becomes an obstacle on the governments' ability to make sufficient level of public services for private sector investment. Corruption may negatively direct resources from human capital formation and more productive investments to less productive investments and thus decreasing the economic growth of countries (Emin \& Alpaslan, 2017, p. 365).

Corruption has a negative effect on competition by putting different restrictions on competition to keep the established firms privileges, corruption can restrict effective competition and so technological development. (Emin \& Alpaslan, 2017, p. 365).

\subsection{Which Comes First Economic Growth or Governance?}

It concerns with economic growth impact on good governance or good governance impact on economic growth. The question is which comes first in economic development good governance or economic growth?

a) Some studies found the differences in long run economic growth performance are due to differences in institutional quality. Also,

b) Some studies found that richer countries are capable of affording the costs that related to providing a competent government bureaucracy, good rules of law and environment in which corruption aren't not 
concerned (Daniel \& Aart, 2003, p. 10).

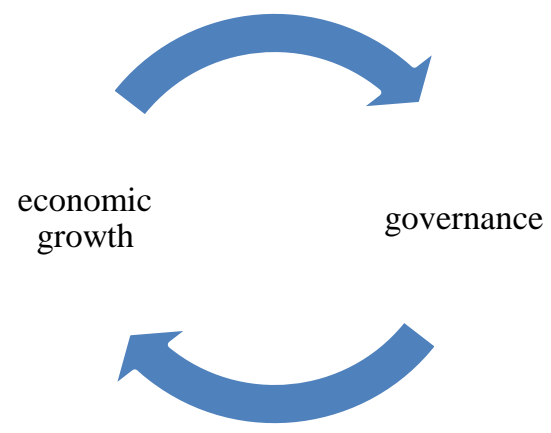

Figure 1. Economic growth \& governance

The direction of economic growth and governance causation is a debated issue; some authors suggest that growth comes first then governance comes as (Glaeser et al., 2004) found that human capital is a cause of economic growth than are the institutions factors.

Also, Rodrik (2008) found that there are many countries that have a high economic growth although they suffer from poor governance. So, he suggests that governance is generally not a necessity for higher economic growth.

Rodrik study suggests that governance doesn't always need economic growth except in rare cases where weak governance is considered as an obstacle for economic growth.

While other studies suggest that governance comes first then growth comes because governance is an necessity for achieving economic growth as (Kaufman \& Kraay, 2002) they found a) better governance has a positive and significant impact on higher economic growth. b) a negative and insignificant effect of economic growth on governance.

This refers to the importance of good governance for economic development and not vice versa.

Also, Paitoon (2018) study found that good governance has an effect on economic growth especially in developing countries. As good governance improve country's competitiveness by enhance efficient use of the country's resources.

\subsection{Does the Relationship between Governance and Economic Growth Differ According the Level of Development?}

The relationship between governance and economic growth differ according to the level of development is a debated issue. The first argument is that there is a positive effect of governance on economic growth and this effect is the same for developing and developed countries.

The result refers to that the only difference between this effect on developing and developed countries are the size of the effect, not in the direction of it. The size differences can often be analysed by factors of development status.

For example (Marie, 2010) analysed the effect of governance on economic growth and the degree of differing this effect according to development country status. It found that good governance affects economic growth positively.

The result refers to that the only difference between this effect on developing and developed countries are the size of the effect, not in the direction of it.

Also the study concluded that these differences in size can be due to factors other than development status.

(Elisa \& Sara, 2011), study examined the effect of good governance on economic growth over sixty years among countries at different development stages. It found that governance affects economic growth positively. The effect is the same for developing and developed countries.

The other point of view suggests that the effect of governance on economic growth is depended on the development level. For example, (Bssam, 2013) study found that countries' levels of development have an impact on the effect of governance on economic growth. In high developed countries, the effect of governance on economic growth was significant after the onset of the global economic crisis except for the effect of voice 
and accountability on economic growth, but in medium developed countries, there was insignificant effect of governance indicators on economic growth after the beginning of the global economic crisis. In low developed countries, control of corruption was the only indicator that had a significant impact on economic growth after the onset of the global economic crisis.

\subsection{Does Crisis Affect the Relationship between Governance and Economic Growth}

(Hasan \& Eridgan, 2017) study found that governance has a positive effect on economic growth. Economic crisis changes governance of countries which in turn has a positive impact on economic growth of countries.

(Bassam, 2013) study analysed whether the effect of governance on economic growth happens during economic crisis or only during non-crisis periods.

It found no changes in this relationship during crisis and during non crisis: effect of governance on economic growth is significant in both periods (before and after the global economic crisis 2008).

\section{Governance in MENA}

If we compare the governance of MENA region to other regions in the world, it ranks below the global average. MENA scores average refers to that the region does not rank above the 50th percentile in any of the 6 indicators of governance (voice and accountability, political stability and absence of violence, government effectiveness, regulatory quality, Rule of law and control of corruption)

\subsection{Voice and Accountability}

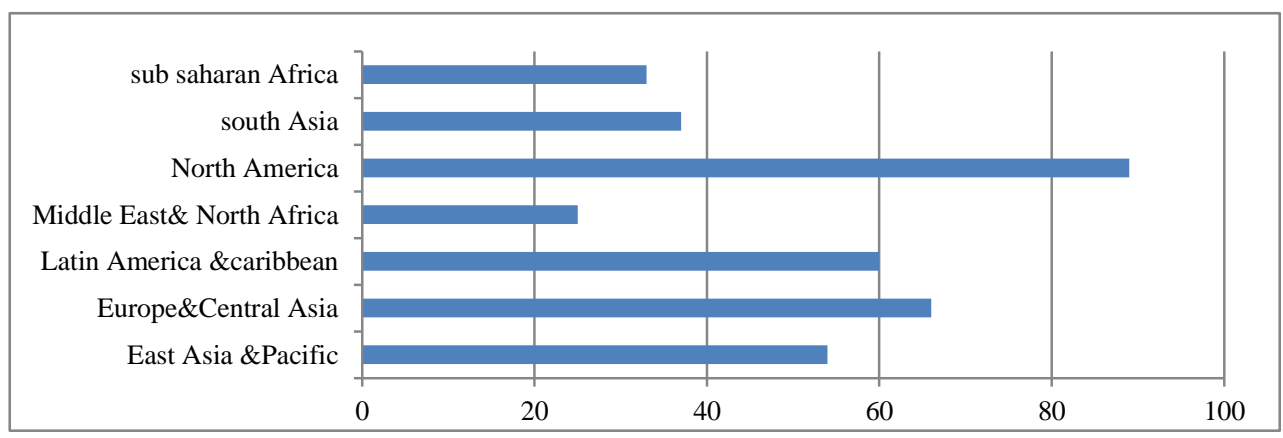

Figure 2. Voice and accountability- 2017

Source: world governance database.

For voice and accountability indicator, in 2017. If compared to the rest of the world, MENA region was the worst rank than the other regions.

Within MENA region, there is wide variation in voice and accountability indicator. In 2017, 18 out of 20 MENA countries ranked below the $50^{\text {th }}$ percentile, 14 of which ranked below the $25^{\text {th }}$ percentile.

Only two countries ranked above the $50^{\text {th }}$ percentile, Israel and Tunisia. So, voice and accountability consider the main problem in MENA.

\subsection{Political Stability and Absence of Violence}

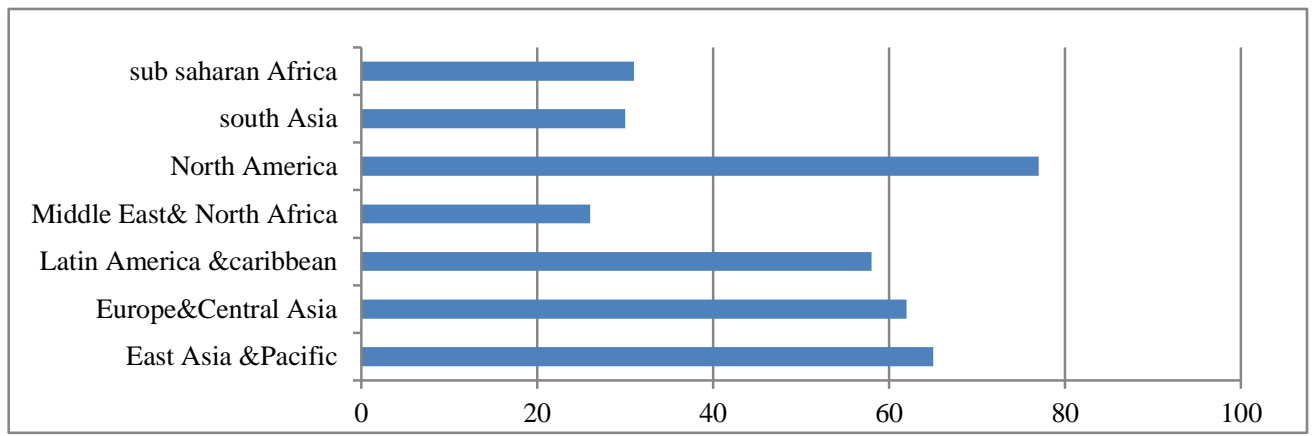

Figure 3. Political stability and absence of violence -2017 
In 2017 and for political stability, MENA region was the worst rank than the other regions.

In 2017,17 out of 20 MENA countries ranked below the $50^{\text {th }}$ percentile, 14 of which ranked below the $25^{\text {th }}$ percentile.

Only three countries ranked above the $50^{\text {th }}$ percentile, United Arab Emirates, Qatar and Oman.

\subsection{Government Effectiveness}

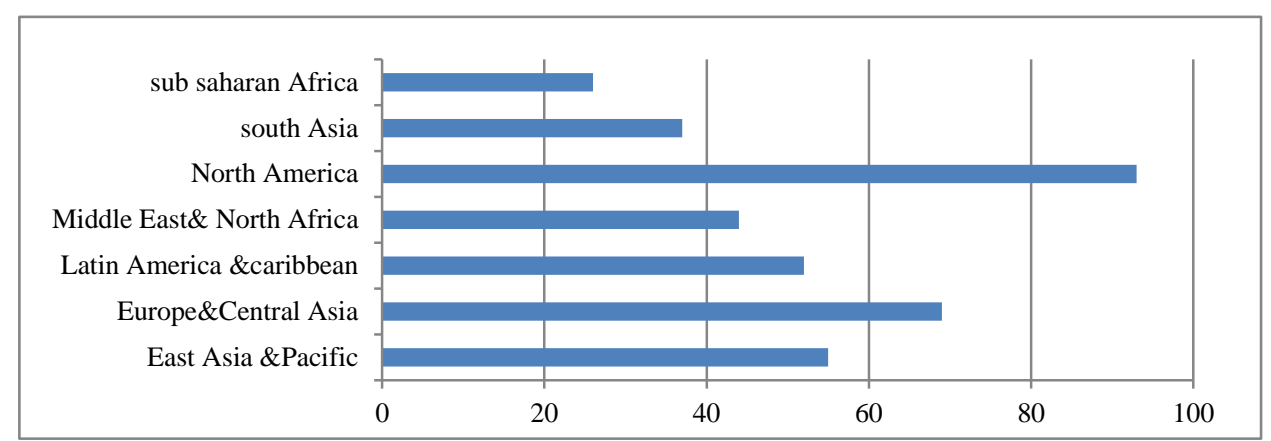

Figure 4. Government effectiveness- 2017

Source: World governance database.

For government effectiveness, if we compare MENA region to other regions in the world, they rank below the global average.

MENA countries lower than East Asia \&Pacific, European and central Asia, latin America and Caribbean and North America. There is only two regions rank lower than MENA: sub Saharan Africa and South Asia.

In 2017,12 out of 20 MENA countries ranked below the $50^{\text {th }}$ percentile, 5 of which ranked below the $25^{\text {th }}$ percentile.

8 countries ranked above the $50^{\text {th }}$ percentile 2 of which ranked above the $75^{\text {th }}$ percentile, United Arab Emirates and Israel. So, MENA countries made improvement in government effectiveness indicator.

\subsection{Regulatory Quality}

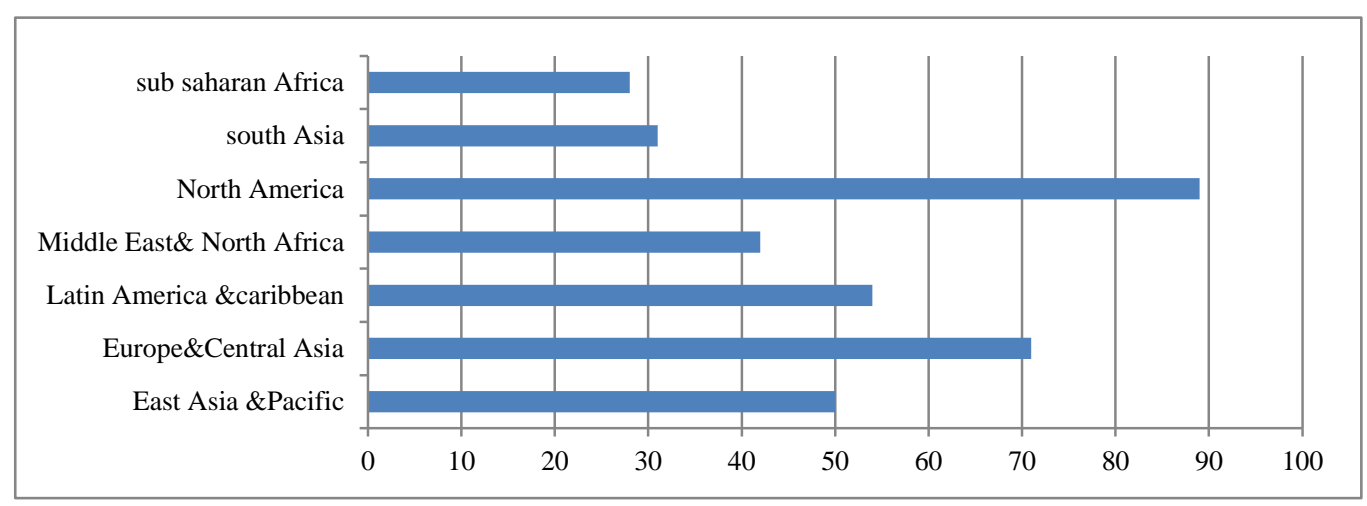

Figure 5. Regulatory quality- 2017

Source: World governance database.

For Regulatory Quality, in comparison with the other regions in the world. MENA ranked below North America, latin America and Caribbean, European and central Asia and East Asia and pacific. And ranked above sub Saharan Africa and south Asia.

In 2017,12 out of 20 MENA countries ranked below the $50^{\text {th }}$ percentile, 8 of which ranked below the $25^{\text {th }}$ percentile.

8 countries ranked above the $50^{\text {th }}$ percentile, only 2 of them ranked above the $75^{\text {th }}$ percentile: united Arab Emirates and Israel. 


\subsection{Rule of Law}

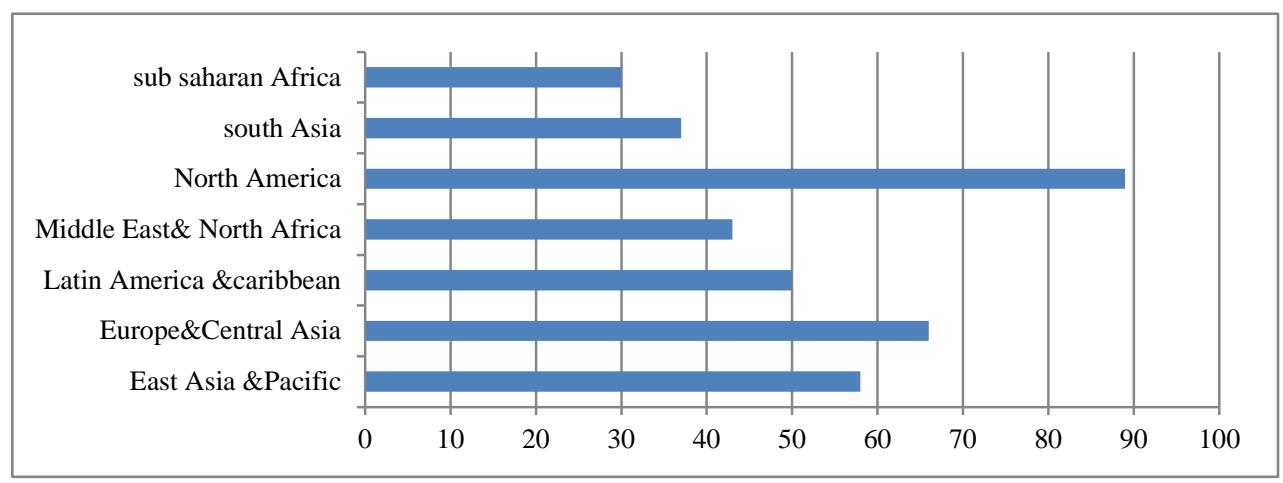

Figure 6. Rule of law- 2017

Source: World governance database.

For Rule of law, MENA ranked below North America, latin America and Caribbean, European and central Asia and East Asia and pacific and ranked above sub Saharan Africa and south Asia.

In 2017, 12 out of 20 MENA countries ranked below the $50^{\text {th }}$ percentile, 8 of which ranked below the $25^{\text {th }}$ percentile.

8 countries ranked above the $50^{\text {th }}$ percentile, only 3 countries ranked above the $75^{\text {th }}$ percentile Qatar, United Arab Emirates and Israel.

\subsection{Control of Corruption}

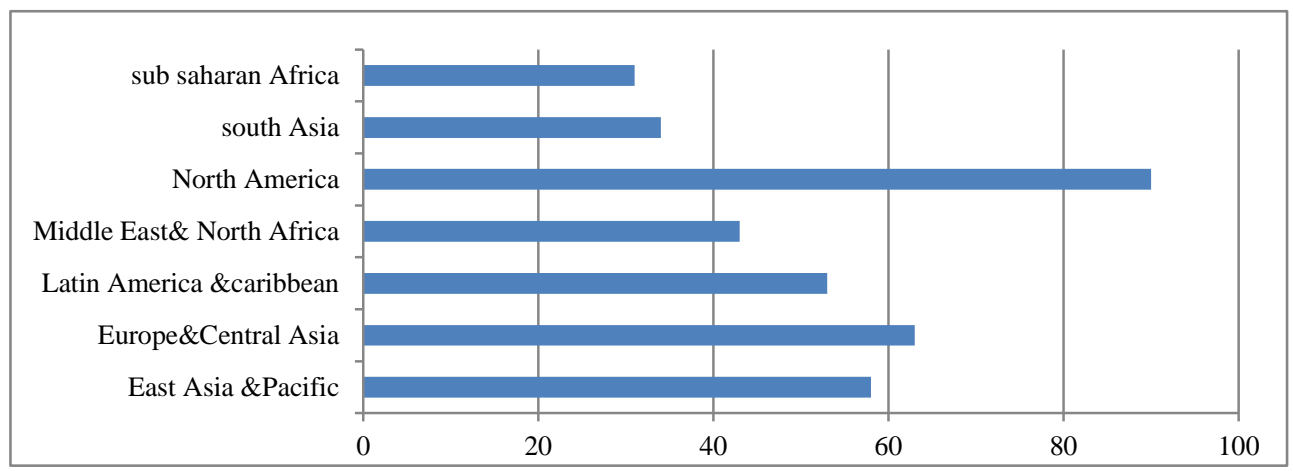

Figure 7. Control of corruption-2017

Source: World governance database.

For control of corruption, MENA ranked below North America, Latin America and Caribbean, European and central Asia and East Asia and pacific and ranked above Sub Saharan Africa and South Asia.

In 2017,11 out of 20 MENA countries ranked below the $50^{\text {th }}$ percentile, 7 of which ranked below the $25^{\text {th }}$ percentile.

9 countries ranked above the $50^{\text {th }}$ percentile. 3 countries ranked above the $75^{\text {th }}$ percentile: United Arab Emirates, Qatar and Israel. These 9 countries are classified as very high and high human Development.

\section{Governance Challenges in MENA}

\subsection{Challenges Related to Voice and Accountability}


Table 1. Democracy index in MENA- 2017

\begin{tabular}{lccccccc}
\hline country & Rank & $\begin{array}{c}\text { Overall } \\
\text { score }\end{array}$ & $\begin{array}{c}\text { Electoral process \& } \\
\text { Pluralism }\end{array}$ & $\begin{array}{c}\text { Functioning of } \\
\text { government }\end{array}$ & $\begin{array}{c}\text { Political } \\
\text { Participation }\end{array}$ & $\begin{array}{c}\text { Political } \\
\text { culture }\end{array}$ & $\begin{array}{c}\text { Civil } \\
\text { liberties }\end{array}$ \\
\hline Israel & 30 & 7.79 & 9.17 & 7.50 & 8.89 & 7.50 & 5.88 \\
Tunisia & 69 & 6.32 & 6.0 & 5.71 & 7.78 & 6.25 & 5.88 \\
Morocoo & 101 & 4.87 & 5.25 & 4.64 & 4.44 & 5.63 & 4.41 \\
lebanon & 104 & 4.72 & 3.50 & 2.57 & 7.22 & 5.63 & 4.71 \\
Iraq & 112 & 4.09 & 4.33 & 0.07 & 7.22 & 5.00 & 3.82 \\
Jordan & 117 & 3.87 & 3.58 & 4.29 & 3.89 & 4.38 & 3.24 \\
Kuwait & 119 & 3.85 & 3.17 & 4.29 & 3.89 & 4.38 & 3.53 \\
Algeria & 128 & 3.56 & 2.58 & 2.21 & 3.89 & 5.00 & 4.12 \\
Egypt & 130 & 3.36 & 3.58 & 3.21 & 3.33 & 3.75 & 2.94 \\
Qatar & 133 & 3.19 & 0.0 & 4.29 & 2.22 & 5.63 & 3.82 \\
Oman & 143 & 3.04 & 0.0 & 3.93 & 2.78 & 4.38 & 4.12 \\
Djibouti & 145 & 2.76 & 0.42 & 1.79 & 3.33 & 5.63 \\
Bahrain & 146 & 2.71 & 0.83 & 3.21 & 2.78 & 4.38 & 3.53 \\
United Arab Emirates & 147 & 2.69 & 0.0 & 3.57 & 2.22 & 5.00 & 2.35 \\
Iran & 150 & 2.45 & 0.0 & 3.21 & 4.44 & 3.13 \\
Libya & 154 & 2.32 & 1.00 & 0.36 & 1.67 & 5.63 & 1.47 \\
Sudan & 155 & 2.15 & 0.0 & 1.79 & 2.78 & 5.00 & 1.18 \\
yemen & 156 & 2.07 & 0.0 & 0.0 & 4.44 & 5.00
\end{tabular}

Source: The Economist Intelligence Unit.

According to the Democracy Index 2017, Israel (Rank 30 out of 167 countries) and Tunisia (Rank 69) are the only 2 countries in MENA categorized in flawed democracies.

Three countries in MENA region classified as Hybrid regime: Morocoo, Lebanon and Iraq. The remaining countries of the MENA are categorized as Authoritarian regimes with the lowest scores in yemen (Rank 156), Saudia Arabia (Rank 159) and Syria (Rank 166).

The main challenges concerned to voice and accountability in MENA region are:

a) Civil society continues to perform under a range of restrictions in MENA region such as restrictions on their ability to work. There are also tight restrictions on funding sources, especially if funds origin is from abroad. (UNDP, 2010, p. 24).

b) Citizens' trust in the government is very low and thus their belief that the accountability of government is also very low. Also, A lack of awareness among citizens of the legislation that exists in the country. (UNDP, 2010, p. 25).

c) A decrease in women participation, ethnic and religious minorities. In most MENA countries, the political arena is always dominated by men from certain ruling group parties (IFES, 2017, p. 17).

d) Democracy does not necessarily guarantee an accountable democratic transition. In many countries in the MENA region, governments used the legitimacy conferred by elections, which often contains repressive laws on human rights, civil society, press freedom and political party formation (IFES, 2017, p. 18).

\subsection{Challenges Related to Political Stability}

Political instability is one of the most important challenges to access good governance in MENA region

The Arab spring leaded to a set of changes in political regime and political domestic instability and insecurity in this region. (Laura, Bassam, \& Richard, 2014, p. 4).

\section{Some of the political causes of political instability in MENA region:}

- Governments have been overthrown in four countries: Tunisia, Egypt, Libya and Yemen

Tunisia was the first country in Arab spring, its president Zien El Abidine fled in January 2011, In Egypt, President Hosni Mubarak resigned in February 2011 after the protests in Tahrir Square which end his years of presidency. 
Libyan leader Mummar Gaddafi was overthrown after international military intervention and was killed in October 2011, Yemen president Ali Abdullah Saleh resigned and his successor Abdal Rabah Mansour AL Hadi formally was instead of him in February 2012. (Erzsebet et al., 2012, p. 1).

- Syria protests wanted resigning of President Bashar El Assad in 2011. The demonstrations leaded to a violent conflict (civil War) between Assad loyalist and opposition forces. (Erzsebet et al., 2012, p. 6).

- Iran's nuclear programme would have very negative effect on the MENA region, especially on the region's security.

\subsection{Challenges Related to Government Effectiveness}

The MENA region is characterized by large public sectors, centralized governments and a complex regulatory structure and regulations.

The MENA public sector represents 6 percent of the total population or 18 percent of the total labour force. While those ratios are within middle income countries' range countries, the evidence refers to representing public sector wage bill in the MENA region 11.1 percent of GDP compared to 8.5 percent for Middle income countries. (Nasser \& Hala, 2003, p. 14).

The MENA region public employee wage bill is one of the highest wage bills in the world. So, administrative reforms like facilitate and implement e government could have a great impact on saving resources through reduction in the cost of government.

Despite that, E- Government can have some advantages in MENA countries in different ways, first enhancing government agencies efficiency. Second, sharing information and ideas among all government agencies and departments to construct one mega database. Third, building confidence among governments and citizens which is an important factor for good governance. Fourth, enhancing transparency, accuracy and facilitating information transformation among government and citizens. Finally, saving resources and efforts.

On the other side, there are various challenges that can delay development of e government application in MENA region:

- Weakness of ICT infrastructure is one of the important barriers for e-government application in MENA region. Also, privacy and security are important barriers in application of e-government.

- Lack of cooperation between all partners is one of the important obstacles in the process of e government application to have a successful e-government system.

- Lack of qualified personnel is an important obstacle to an e- government application.

- Lack of financial resources is a significant barrier to the application of e-government in MENA region. (Alshehri \& Drew, 2010, pp. 83-86).

6.4 Challenges Related to Rule of Law

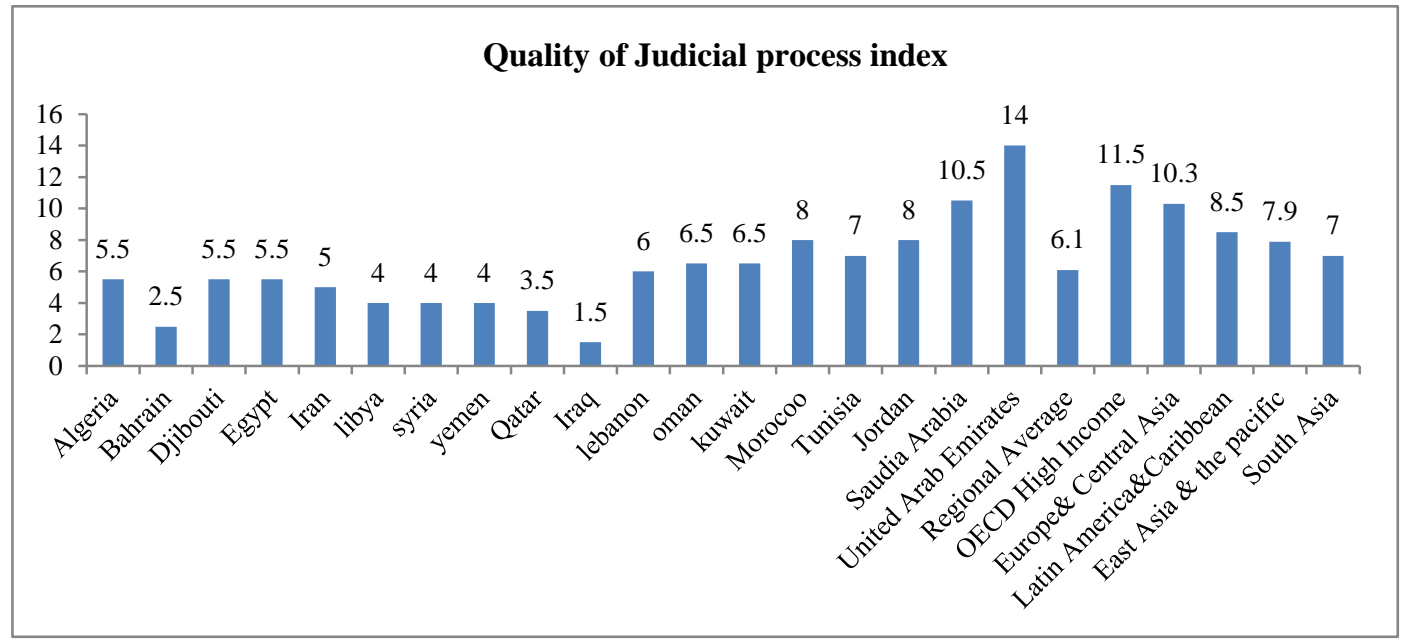

Figure 8. Quality of judicial process

Source: Doing Business database. 


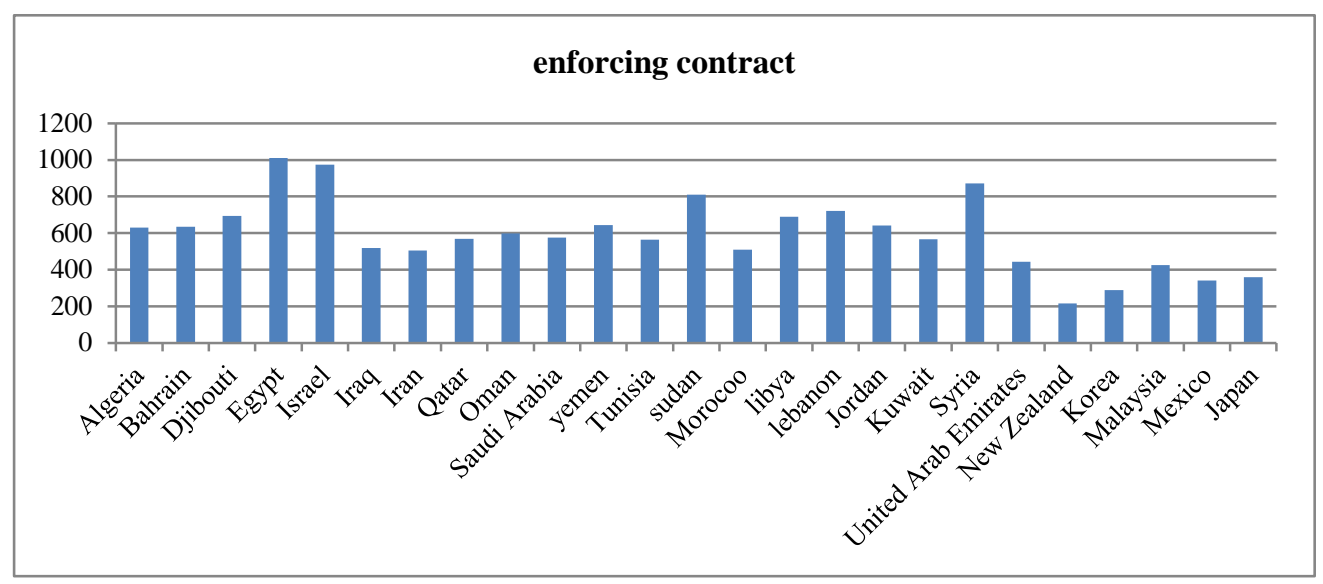

Figure 9. Enforcing contract in MENA region

Source: Doing Business database.

In this context, The United Arab Emirates made reforms to facilitate contract enforcement by the implementation of electronic services, introduction of a new case management office with the complete court and the development of the services that allowing litigants to file and tract motions in an online way.

Iran achieved electronic filing of documents, text message notification and electronic case management systems and these developments in Iran enhance Iran's rank.

Saudi Arabia developed its courts computerisation and introduced electronic filing of documents.

\subsection{Challenges Related to Regulatory Quality}

The main obstacle that faces MENA region concerning regulatory quality is overregulation that can decreases investment by increasing the start-up and operation business costs. There are a lot of cumbersome procedures that represent costs for actual and potential investors.

In MENA region, customs processing is an important obstacle on the competitiveness of international firms. MENA entrepreneurs find that a business registration is a long procedure that imposes a lot of times and is often very costly. (World Bank, 2010, pp. 94-95).

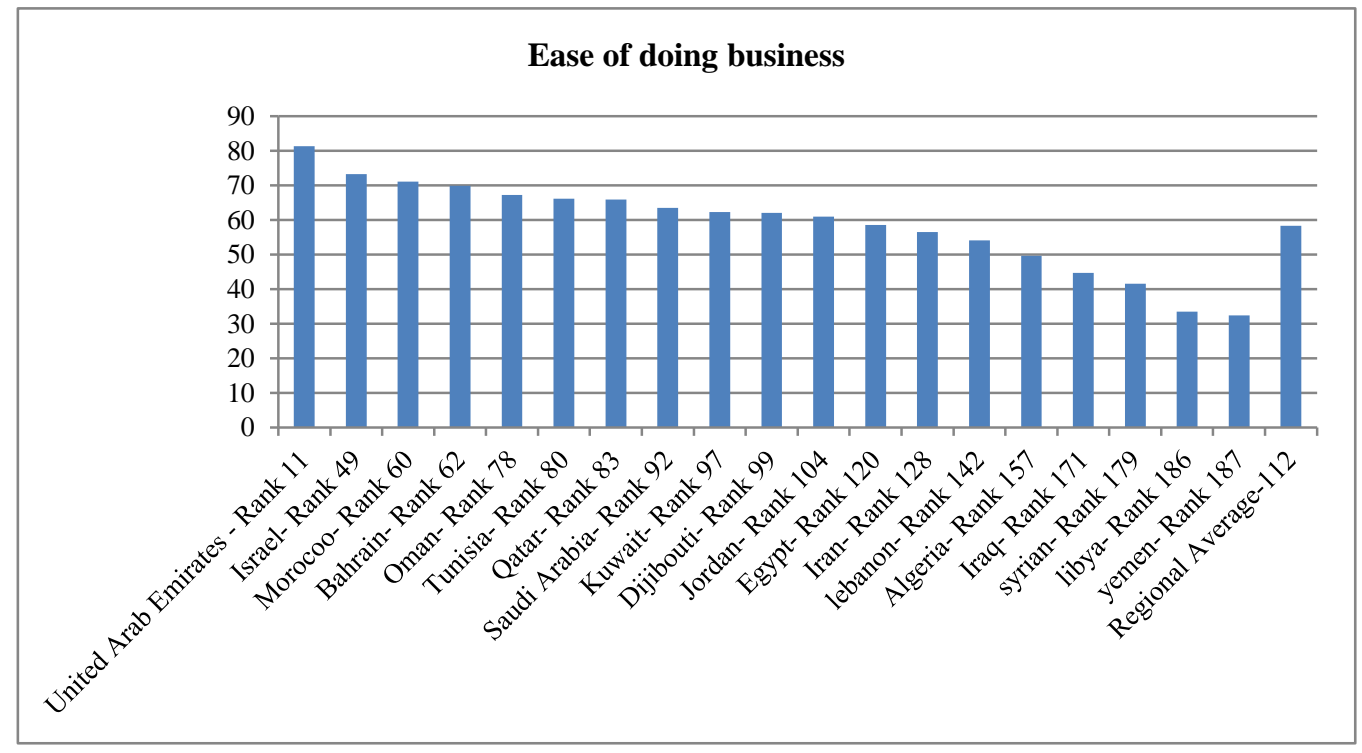

Figure 10. Ease of doing business- 2019

Source: Doing Business database.

Comparing to other regions, MENA is one of the lowest region with average score (58.3) while Europe \& Central Asia score is (72.34) and East Asia \& Pacific score is (63.41). 
MENA countries rank 112 in terms of ease of doing business indicator. These areas are ranking in starting a business indicator (Rank 113), enforcing contracts indicator (Rank 105), getting credit indicator (Rank 126) and trading across borders indicator (Rank 121).

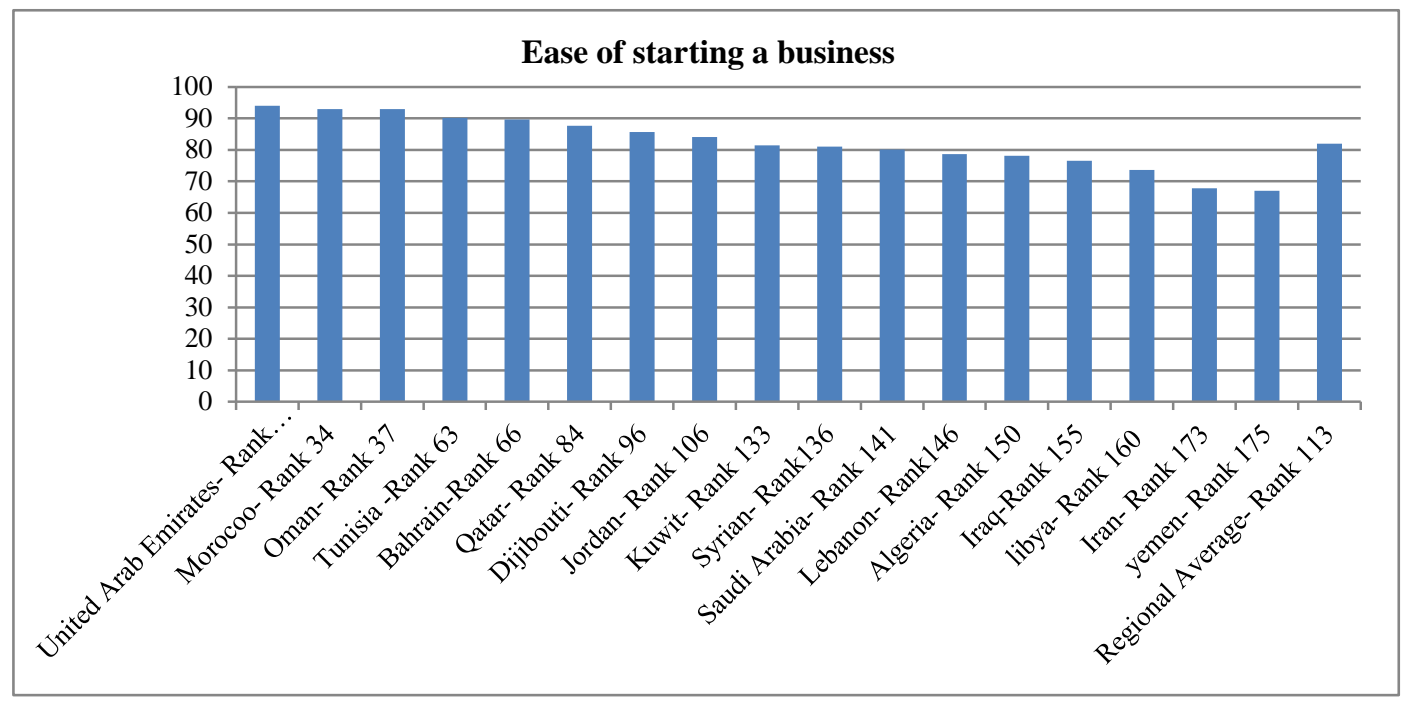

Figure 11. Ease of starting a business- 2019

Source: Doing Business database.

For starting a business indicator (2019) MENA score is 82 which is relatively low compared to other regions like East Asia \& Pacific score (83.29), South Asia score (85.44) and Europe \& Central Asia score (90.02).

Although a number of MENA economies adopted reforms for starting a business, the 2019 doing business report only ranks United Arab Emirates, Oman \& Morocco in the top 50 countries.

We find that a great number of MENA economies ranks above 100 like: Jordan, Kuwait, Syrian, Saudi Arabia, Lebanon, Algeria, Iraq, Libya, Iran and Yemen.

6.6 Challenges Related to Control of Corruption

Table 2. CPI (Corruption Perception Index) in MENA (2012-2017)

\begin{tabular}{|c|c|c|c|c|c|c|}
\hline CPI & 2012 & 2013 & 2014 & 2015 & 2016 & 2017 \\
\hline United Arab Emirates & 68 & 69 & 70 & 70 & 66 & 71 \\
\hline Israel & 60 & 61 & 60 & 61 & 64 & 62 \\
\hline Qatar & 68 & 68 & 69 & 71 & 61 & 63 \\
\hline Jordan & 48 & 45 & 49 & 53 & 48 & 48 \\
\hline Oman & 47 & 47 & 45 & 45 & 45 & 44 \\
\hline Bahrain & 51 & 48 & 49 & 51 & 43 & 36 \\
\hline Kuwait & 44 & 43 & 44 & 49 & 41 & 39 \\
\hline Tunisia & 41 & 41 & 40 & 38 & 41 & 42 \\
\hline Algeria & 34 & 36 & 36 & 36 & 34 & 33 \\
\hline Egypt & 32 & 32 & 37 & 36 & 34 & 32 \\
\hline Iran & 28 & 25 & 27 & 27 & 29 & 30 \\
\hline Lebanon & 30 & 28 & 27 & 28 & 28 & 28 \\
\hline Iraq & 18 & 16 & 16 & 16 & 17 & 18 \\
\hline libya & 21 & 15 & 18 & 16 & 14 & 17 \\
\hline Morocoo & 37 & 37 & 39 & 36 & 37 & 40 \\
\hline Yemen & 23 & 18 & 19 & 18 & 14 & 16 \\
\hline Syria & 26 & 17 & 20 & 18 & 13 & 14 \\
\hline Saudia Arabia & 44 & 46 & 49 & 52 & 46 & 49 \\
\hline Sudan & 13 & 11 & 11 & 12 & 14 & 16 \\
\hline Djibouti & 36 & 36 & 34 & 34 & 30 & 31 \\
\hline Average & 38.45 & 36.95 & 37.95 & 38.35 & 35.95 & 36.45 \\
\hline
\end{tabular}

Source: Transparency International. 
Corruption has raised during the period (2012-2017) in MENA region.as CPI decreased from 38.45 in 2012 to 36.45 in 2017. Countries like Syria, Djibouti, Yemen, Lebanon, Kuwait, Qatar and Bahrain failed in decreasing corruption during the period (2012-2017), while other countries like Egypt, Tunisia, Jordan and Algeria stabilized corruption during the period 2012-2017.

There are two classes of corruption in the public sector: high level corruption which called grand corruption, where top level policymakers use the governance process for financial gains(failure of policy environment) and the second type is low level corruption or bureaucratic corruption. A failure in accountability structures can leads to both of them (World Bank, 2003, p. 97).

There are many reasons that are obstacles to the efforts of ending corruption in MENA region:

1) Political factors: political instability results in raising corruption. In Syria, corruption increases during the period (2012-2017). CPI decreased from 26 in 2012 to 14 in 2016. Also, In Yemen, Consumer Price index decreased from 23 in 2012 to 16 in 2016.

2) Economic factors: a decrease in income level can lead to corruption by directing the work ethics of individuals or organizations to illegal works in order to ensure income increment that make an important effect on the living conditions of individuals. (Salih \& Ali, 2016, p. 121).

Also, Inflation lead to unequal distribution of the national income and the diminishment of the real income level of a large part of the Society. Inflation could lead to reduction in real income for individuals and decrease in their purchasing power. So they may tend towards illegal activities such as bribery, fraud in order to satisfy their basic needs and ensure certain financial level. (Salih \& Ali, 2016, p. 121).

\section{Estimating the Impact of Governance on Economic Growth and Human Development}

This section deals with the analysis, measurement and identification of the impact of governance on economic growth and human development in 20 countries during the period (1996-2017) using E views 10.

Table 3. Variable specification

\begin{tabular}{lllc}
\hline \multicolumn{1}{c}{ Variables Nature } & \multicolumn{1}{c}{ Variables } & Symbol \\
\hline & & Voice and accountability & $\mathrm{X}_{1}$ \\
& & Political stability & $\mathrm{X}_{2}$ \\
Independent Variable & \multirow{2}{*}{ Governance } & Government effectiveness & $\mathrm{X}_{3}$ \\
& & Regulatory Quality & $\mathrm{X}_{4}$ \\
& & Rule of law & $\mathrm{X}_{5}$ \\
& & Control of corruption & $\mathrm{X}_{6}$ \\
Dependent Variable & Economic growth & GDP growth & $\mathrm{Y}_{1}$ \\
& Human Development & Human Development Index & $\mathrm{Y}_{2}$ \\
\hline
\end{tabular}

Since our study is based on data of 20 countries during the period (1996-2017) we used panel data (longitudinal data) which combines cross sectional data and time series data by applying the three longitudinal data models.

a) Pooled Regression Model

b) Fixed effect Model

c) Random effect Model

$$
\begin{gathered}
\mathrm{Y}_{i t}=\beta_{0}+\beta_{1} \mathrm{X}_{1 i t}+\beta_{2} \mathrm{X}_{2 i t}+\beta_{3} \mathrm{X}_{3 i t}+\beta_{4} \mathrm{X}_{4 i t}+\beta_{5} \mathrm{X}_{5 i t}+\beta_{6} \mathrm{X}_{6 i t}+u_{i t} \\
\mathrm{Y}_{i t}=\beta_{0 i}+\beta_{1} \mathrm{X}_{1 i t}+\beta_{2} \mathrm{X}_{2 i t}+\beta_{3} \mathrm{X}_{3 i t}+\beta_{4} \mathrm{X}_{4 i t}+\beta_{5} \mathrm{X}_{5 i t}+\beta_{6} \mathrm{X}_{6 i t}+u_{i t} \\
\mathrm{Y}_{i t}=\beta_{0}+\beta_{1} \mathrm{X}_{1 i t}+\beta_{2} \mathrm{X}_{2 i t}+\beta_{3} \mathrm{X}_{3 i t}+\beta_{4} \mathrm{X}_{4 i t}+\beta_{5} \mathrm{X}_{5 i t}+\beta_{6} \mathrm{X}_{6 i t}+\varepsilon_{i}+u_{i t}
\end{gathered}
$$

Where:

$Y_{i t}$ : GDP growth/ Human development for country i during the period $t$;

$\mathrm{X}_{1 i t}$ : Voice and accountability for country $\mathrm{i}$ during the period $\mathrm{t}$;

$\mathrm{X}_{2 i t}$ : Political stability for country i during the period $\mathrm{t}$;

$\mathrm{X}_{3 i t}$ : Government effectiveness for country i during the period $\mathrm{t}$;

$\mathrm{X}_{4 i t}$ : Regulatory Quality for country i during the period $\mathrm{t}$; 
$\mathrm{X}_{5 i t}$ : Rule of law for country $\mathrm{i}$ during the period $\mathrm{t}$;

$\mathrm{X}_{6 i t}$ : control of corruption for country i during the period $\mathrm{t}$;

$\varepsilon_{i}$ : the random error for each country;

$u_{i t}$ : the random error from the regression model.

Table 4. Variable descriptive analysis

\begin{tabular}{|c|c|c|c|c|c|c|}
\hline \multirow{2}{*}{ Variables } & \multirow{2}{*}{ Sample Size } & \multicolumn{5}{|c|}{ Descriptive Statistics } \\
\hline & & Min Value & Max Value & Mean & Median & Standard Deviation \\
\hline $\begin{array}{l}\text { Voice and accountability } \\
\qquad\left(\mathrm{X}_{1}\right)\end{array}$ & 440 & -2.100 & 0.800 & -0.996 & -1.000 & 0.597 \\
\hline $\begin{array}{c}\text { Political stability } \\
\qquad\left(\mathrm{X}_{2}\right)\end{array}$ & 440 & -3.200 & 1.200 & -0.657 & -0.525 & 1.050 \\
\hline $\begin{array}{c}\text { Government effectiveness } \\
\qquad\left(\mathrm{X}_{3}\right)\end{array}$ & 440 & -2.100 & 1.500 & -0.278 & -0.235 & 0.778 \\
\hline $\begin{array}{c}\text { Regulatory Quality } \\
\qquad\left(\mathrm{X}_{4}\right)\end{array}$ & 440 & -2.930 & 1.300 & -0.367 & -0.200 & 0.855 \\
\hline $\begin{array}{c}\text { Rule of law } \\
\left(\mathrm{X}_{5}\right)\end{array}$ & 440 & -2.690 & 1.300 & -0.331 & -0.215 & 0.794 \\
\hline $\begin{array}{l}\text { Control of corruption } \\
\qquad\left(\mathrm{X}_{6}\right)\end{array}$ & 440 & -2.390 & 1.600 & -0.307 & -0.400 & 0.773 \\
\hline $\begin{array}{l}\text { Economic growth } \\
\left(\mathrm{Y}_{1}\right)\end{array}$ & 440 & -62.080 & 123.14 & 4.275 & 4.085 & 9.227 \\
\hline $\begin{array}{c}\text { Human Development } \\
\left(\mathrm{Y}_{2}\right)\end{array}$ & 440 & 0.353 & 0.932 & 0.688 & 0.719 & 0.132 \\
\hline
\end{tabular}

From the table above we found that the value of the standard deviation is greater than the mean for all the variables and the difference between the maximum and minimum (range) is too large which indicates that the data suffers from the existence of some extreme values outliers. This may be due to the difference in characteristics of the countries over time periods. This gives initial indication that the appropriate model would be fixed effects model or Random effect model.

Table 5. Correlation matrix

\begin{tabular}{|c|c|c|c|c|c|c|c|c|c|}
\hline Variables & Correlation & $\mathbf{X}_{1}$ & $\mathbf{X}_{2}$ & $\mathbf{X}_{3}$ & $\mathbf{X}_{4}$ & $\mathbf{X}_{5}$ & $\mathbf{X}_{6}$ & $\mathbf{Y}_{1}$ & $\mathbf{Y}_{2}$ \\
\hline $\begin{array}{l}\text { Voice and accountability } \\
\qquad\left(\mathbf{X}_{1}\right)\end{array}$ & $\begin{array}{c}\mathbf{r} \\
p \text {-value }\end{array}$ & 1 & & & & & & & \\
\hline $\begin{array}{c}\text { Political stability } \\
\left(\mathbf{X}_{2}\right)\end{array}$ & $\begin{array}{c}\mathbf{r} \\
p \text {-value }\end{array}$ & $\begin{array}{l}0.171 \\
0.000\end{array}$ & 1 & & & & & & \\
\hline $\begin{array}{c}\text { Government effectiveness } \\
\qquad\left(\mathbf{X}_{\mathbf{3}}\right)\end{array}$ & $\begin{array}{c}\mathbf{r} \\
p \text {-value }\end{array}$ & $\begin{array}{l}0.574 \\
0.000\end{array}$ & $\begin{array}{l}0.590 \\
0.000\end{array}$ & 1 & & & & & \\
\hline $\begin{array}{l}\text { Regulatory Quality } \\
\qquad\left(\mathbf{X}_{\mathbf{4}}\right)\end{array}$ & $\begin{array}{c}\mathbf{r} \\
p \text {-value }\end{array}$ & $\begin{array}{l}0.565 \\
0.000\end{array}$ & $\begin{array}{l}0.553 \\
0.000\end{array}$ & $\begin{array}{l}0.829 \\
0.000\end{array}$ & 1 & & & & \\
\hline $\begin{array}{c}\text { Rule of law } \\
\left(\mathbf{X}_{5}\right)\end{array}$ & $\begin{array}{c}\mathbf{r} \\
p \text {-value }\end{array}$ & $\begin{array}{l}0.556 \\
0.000\end{array}$ & $\begin{array}{l}0.640 \\
0.000\end{array}$ & $\begin{array}{l}0.856 \\
0.000\end{array}$ & $\begin{array}{l}0.813 \\
0.000\end{array}$ & 1 & & & \\
\hline $\begin{array}{c}\text { Control of corruption } \\
\qquad\left(\mathbf{X}_{6}\right)\end{array}$ & $\begin{array}{c}\mathbf{r} \\
p \text {-value }\end{array}$ & $\begin{array}{l}0.534 \\
0.000\end{array}$ & $\begin{array}{l}0.629 \\
0.000\end{array}$ & $\begin{array}{l}0.860 \\
0.000\end{array}$ & $\begin{array}{l}0.803 \\
0.000\end{array}$ & $\begin{array}{l}0.861 \\
0.000\end{array}$ & 1 & & \\
\hline $\begin{array}{c}\text { Economic growth } \\
\left(\mathbf{Y}_{1}\right)\end{array}$ & $p$-value & $\begin{array}{c}-0.001 \\
0.989\end{array}$ & $\begin{array}{c}-0.002 \\
0.970\end{array}$ & $\begin{array}{c}-0.004 \\
0.928\end{array}$ & $\begin{array}{l}-0.011 \\
0.811\end{array}$ & $\begin{array}{l}0.008 \\
0.870\end{array}$ & $\begin{array}{l}0.011 \\
0.810\end{array}$ & $\mathbf{1}$ & \\
\hline $\begin{array}{c}\text { Human Development } \\
\left(\mathbf{Y}_{2}\right)\end{array}$ & $\begin{array}{c}\mathbf{r} \\
p \text {-value }\end{array}$ & $\begin{array}{l}0.398 \\
0.000\end{array}$ & $\begin{array}{l}0.448 \\
0.000\end{array}$ & $\begin{array}{l}0.702 \\
0.000\end{array}$ & $\begin{array}{l}0.596 \\
0.000 \\
\end{array}$ & $\begin{array}{l}0.708 \\
0.000 \\
\end{array}$ & $\begin{array}{l}0.667 \\
0.000 \\
\end{array}$ & $\begin{array}{l}0.016 \\
0.733 \\
\end{array}$ & 1 \\
\hline
\end{tabular}

This table shows that there is no statistically significant relation between governance and economic growth at significant level 5\%. As the correlation coefficient exceed the absolute value ( $\mathrm{p}-$ value $<\alpha=0.05$ ).

Also, there is a positive statistically significant relation between governance and human development (Y2) at significant level of 5\% as the correlation coefficient less than the absolute value ( $\mathrm{p}$ - value $=0.000<\alpha=0.05$ ). 
Table 6. Unit root tests

\begin{tabular}{|c|c|c|c|c|c|c|c|}
\hline \multirow{2}{*}{ Variables } & \multirow{2}{*}{ Diff. } & \multicolumn{2}{|c|}{ Levin, Lin \& Chu t test } & \multicolumn{2}{|c|}{ ADF - Fisher Chi-square test } & \multicolumn{2}{|c|}{ PP - Fisher Chi-square test } \\
\hline & & Value & p-value & Value & $p$-value & Value & $p$-value \\
\hline Voice and accountability & Level & -3.73179 & 0.0001 & 136.752 & 0.0000 & 213.058 & 0.0000 \\
\hline$\left(\mathbf{X}_{1}\right)$ & $1^{\text {st }}$ Diff. & -33.6472 & 0.0000 & 409.386 & 0.0000 & 531.426 & 0.0000 \\
\hline Political stability & Level & -4.57434 & 0.0000 & 120.051 & 0.0000 & 168.964 & 0.0000 \\
\hline$\left(\mathbf{X}_{2}\right)$ & $1^{\text {st }}$ Diff. & -29.2283 & 0.0000 & 449.855 & 0.0000 & 493.107 & 0.0000 \\
\hline Government effectiveness & Level & -1.35814 & 0.0072 & 107.859 & 0.0000 & 219.988 & 0.0000 \\
\hline$\left(\mathbf{X}_{3}\right)$ & $1^{\text {st }}$ Diff. & -50.093 & 0.0000 & 412.524 & 0.0000 & 486.582 & 0.0000 \\
\hline Regulatory Quality & Level & -4.93221 & 0.0000 & 102.05 & 0.0000 & 172.566 & 0.0000 \\
\hline$\left(\mathbf{X}_{4}\right)$ & $1^{\text {st }}$ Diff. & -33.5447 & 0.0000 & 401.95 & 0.0000 & 505.398 & 0.0000 \\
\hline Rule of law & Level & -5.0908 & 0.0000 & 148.03 & 0.0000 & 198.349 & 0.0000 \\
\hline$\left(\mathbf{X}_{\mathbf{5}}\right)$ & $1^{\text {st }}$ Diff. & -37.6344 & 0.0000 & 456.284 & 0.0000 & 481.814 & 0.0000 \\
\hline Control of corruption & Level & -5.4761 & 0.0000 & 134.808 & 0.0000 & 250.93 & 0.0000 \\
\hline$\left(\mathbf{X}_{6}\right)$ & $1^{\text {st }}$ Diff. & -37.7547 & 0.0000 & 456.88 & 0.0000 & 523.052 & 0.0000 \\
\hline Economic growth & Level & -9.42809 & 0.0000 & 193.138 & 0.0000 & 447.815 & 0.0000 \\
\hline$\left(\mathbf{Y}_{1}\right)$ & $1^{\text {st }}$ Diff. & -25.4809 & 0.0000 & 463.206 & 0.0000 & 464.991 & 0.0000 \\
\hline Human Development & Level & -8.34516 & 0.0000 & 76.468 & 0.0005 & 101.009 & 0.0000 \\
\hline$\left(\mathbf{Y}_{2}\right)$ & $1^{\text {st }}$ Diff. & -7.42637 & 0.0000 & 188.422 & 0.0000 & 199.488 & 0.0000 \\
\hline
\end{tabular}

This table shows the stability of all the variables of the study in their original level and are stable when take the first differences as the value is less than the absolute value ( $p$ - value $<\alpha=0.05$ ).

So the time series of the variables integrated at the same level i.e from $\mathrm{I}(0)$ which mean it is accepted to apply multiple regression model using OLS to determine the relation between dependent and independent variables.

7.1 Determine the Impact of Governance on Economic Growth

Table 7. Pooled, fixed and Random Models summary

\begin{tabular}{|c|c|c|c|c|c|c|c|c|c|c|c|c|}
\hline \multirow{3}{*}{ Variables } & \multicolumn{4}{|c|}{ Pooled Regression Model } & \multicolumn{4}{|c|}{ Fixed Effect Model } & \multicolumn{4}{|c|}{ Random Effect Model } \\
\hline & \multicolumn{2}{|c|}{ Coefficients } & \multicolumn{2}{|c|}{ t-test } & \multicolumn{2}{|c|}{ Coefficients } & \multicolumn{2}{|c|}{ t-test } & \multicolumn{2}{|c|}{ Coefficients } & \multicolumn{2}{|c|}{ t-test } \\
\hline & Value & Std. Error & $\mathbf{t}$ & $p$-value & Value & Std. Error & $\mathbf{t}$ & $p$-value & Value & Std. Error & $\mathbf{t}$ & $p$-value \\
\hline Constant & 4.2127 & 1.0481 & 4.0194 & 0.0001 & 5.8763 & 1.5334 & 3.8324 & 0.0001 & 4.2127 & 1.0579 & 3.9819 & 0.0001 \\
\hline $\mathrm{X}_{1}$ & -0.0253 & 0.9852 & -0.0257 & 0.9795 & 0.9537 & 1.4342 & 0.6650 & 0.5064 & -0.0253 & 0.9944 & -0.0254 & 0.9797 \\
\hline $\mathbf{X}_{2}$ & -0.1281 & 0.5950 & -0.2152 & 0.8297 & -0.0425 & 0.7944 & -0.0534 & 0.9574 & -0.1281 & 0.6006 & -0.2132 & 0.8313 \\
\hline $\mathbf{X}_{3}$ & -0.4901 & 1.3388 & -0.3661 & 0.7145 & -0.5071 & 1.4929 & -0.3397 & 0.7343 & -0.4901 & 1.3514 & -0.3627 & 0.7170 \\
\hline $\mathbf{X}_{4}$ & -0.5823 & 1.0204 & -0.5706 & 0.5685 & 0.4071 & 1.2674 & 0.3212 & 0.7482 & -0.5823 & 1.0300 & -0.5653 & 0.5722 \\
\hline $\mathbf{X}_{5}$ & 0.4888 & 1.3109 & 0.3729 & 0.7094 & 1.0996 & 1.5908 & 0.6912 & 0.4898 & 0.4888 & 1.3233 & 0.3694 & 0.7120 \\
\hline $\mathbf{X}_{6}$ & 0.7669 & 1.3171 & 0.5822 & 0.5607 & 0.9986 & 1.4399 & 0.6935 & 0.4884 & 0.7669 & 1.3295 & 0.5768 & 0.5644 \\
\hline \multicolumn{13}{|c|}{ Model Summary } \\
\hline $\mathbf{R}^{2}$ & \multicolumn{4}{|c|}{0.001888} & \multicolumn{4}{|c|}{0.027623} & \multicolumn{4}{|c|}{0.001888} \\
\hline Adjusted $\mathbf{R}^{2}$ & \multicolumn{4}{|c|}{-0.011943} & \multicolumn{4}{|c|}{-0.031095} & \multicolumn{4}{|c|}{-0.011943} \\
\hline Std. Error & \multicolumn{4}{|c|}{9.281491} & \multicolumn{4}{|c|}{9.368912} & \multicolumn{4}{|c|}{9.281491} \\
\hline $\mathbf{F}$ & \multicolumn{4}{|c|}{0.136497} & \multicolumn{4}{|c|}{0.470433} & \multicolumn{4}{|c|}{0.136497} \\
\hline$p$-value & \multicolumn{4}{|c|}{0.991471} & \multicolumn{4}{|c|}{0.987227} & \multicolumn{4}{|c|}{0.991471} \\
\hline
\end{tabular}

To determine the appropriate panel model we used:
a) Wald test (Restricted $\mathrm{F}$ test)
b) Breusch pagan LM (lagrange Multiplier test)
c) Hausman test

Table 8. Wald, LM and Hausman tests

\begin{tabular}{cccccccc}
\hline \multicolumn{2}{c}{ Wald test } & \multicolumn{2}{c}{ LM (Lagrange Multiplier) test } & \multicolumn{2}{c}{ Hausman test } & \multicolumn{2}{c}{ Co-integration test (Kao test) } \\
\hline F & $p$-value & Breusch-Pagan & $p$-value & $\chi^{2}$ & $p$-value & t & $p$-value \\
\hline 0.576687 & $\mathbf{0 . 9 2 2 6}$ & 4.013655 & 0.0451 & 3.737952 & 0.7121 & 2.54976 & 0.0054 \\
\hline
\end{tabular}




\section{Determining the appropriate panel model:}

a) Wald test ( $\mathrm{f}$ test):

$\mathrm{p}$-value $=0.9226>\alpha=0.05$ which indicate that pooled OLS model is better than the fixed effect model.

b) Breusch pagan test statistic:

p-value $=0.0451<\alpha=0.05$ which indicate that Random effect model is better than pooled OLS model.

c) Hausman test statistic:

p-value $=0.7121<\alpha=0.05$ which indicate that random effects model is better than fixed effect model.

Therefore, the best estimating model for panel regression to determine the relation between governance and Economic growth is Random effect model.

According to Random effect model, no significant impact of governance on economic growth.

7.2 Determining the Impact of the Financial Crisis on the Relationship between Governance and Economic Growth

In order to determine the impact of the 2008 global financial crisis on the relationship between governance (independent variables) and the economic growth (dependent variables), the study period was divided into two periods (1996-2007) and (2008-2017) the results were as follows: the correlation between the indicators of the governance and the economic growth was insignificant at a significant level of 0.05 during the two study periods (1996-2007) and (2008-2017) indicating that financial crisis didn't affect the relationship between governance and economic growth.

\subsection{Determine the Impact of Governance on Human Development}

Table 9. Pooled, fixed and random models summary

\begin{tabular}{|c|c|c|c|c|c|c|c|c|c|c|c|c|}
\hline \multirow{3}{*}{ Variables } & \multicolumn{4}{|c|}{ Pooled Regression Model } & \multicolumn{4}{|c|}{ Fixed Effect Model } & \multicolumn{4}{|c|}{ Random Effect Model } \\
\hline & \multicolumn{2}{|c|}{ Coefficients } & \multicolumn{2}{|c|}{ t-test } & \multicolumn{2}{|c|}{ Coefficients } & \multicolumn{2}{|c|}{ t-test } & \multicolumn{2}{|c|}{ Coefficients } & \multicolumn{2}{|c|}{ t-test } \\
\hline & Value & Std. Error & $\mathbf{t}$ & $p$-value & Value & Std. Error & $\mathbf{t}$ & $p$-value & Value & Std. Error & t & $p$-value \\
\hline Constant & 0.7122 & 0.0102 & 70.1709 & 0.0000 & 0.6764 & 0.0057 & 119.310 & 0.0000 & 0.6794 & 0.0185 & 36.7232 & 0.0000 \\
\hline $\mathrm{X}_{1}$ & -0.0128 & 0.0095 & -1.3405 & 0.1808 & -0.0195 & 0.0053 & -3.6803 & 0.0003 & -0.0185 & 0.0053 & -3.5125 & 0.0005 \\
\hline $\mathbf{X}_{2}$ & -0.0080 & 0.0058 & -1.3818 & 0.1678 & -0.0084 & 0.0029 & -2.8679 & 0.0043 & -0.0085 & 0.0029 & -2.8935 & 0.0040 \\
\hline $\mathbf{X}_{3}$ & 0.0660 & 0.0130 & 5.0895 & 0.0000 & 0.0160 & 0.0055 & 2.9022 & 0.0039 & 0.0173 & 0.0055 & 3.1350 & 0.0018 \\
\hline $\mathbf{X}_{4}$ & -0.0157 & 0.0099 & -1.5856 & 0.1136 & 0.0086 & 0.0047 & 1.8454 & 0.0657 & 0.0098 & 0.0047 & 2.1022 & 0.0361 \\
\hline $\mathbf{X}_{5}$ & 0.0725 & 0.0127 & 5.7088 & 0.0000 & 0.0278 & 0.0059 & 4.7321 & 0.0000 & 0.0302 & 0.0059 & 5.1613 & 0.0000 \\
\hline$X_{6}$ & 0.0189 & 0.0128 & 1.4785 & 0.1400 & -0.0105 & $\mathbf{0 . 0 0 5 3}$ & -1.9729 & 0.0492 & -0.0090 & 0.0053 & -1.6906 & 0.0916 \\
\hline \multicolumn{13}{|c|}{ Model Summary } \\
\hline $\mathbf{R}^{2}$ & \multicolumn{4}{|c|}{0.543179} & \multicolumn{4}{|c|}{0.935123} & \multicolumn{4}{|c|}{0.128963} \\
\hline Adjusted $R^{2}$ & \multicolumn{4}{|c|}{0.536849} & \multicolumn{4}{|c|}{0.931205} & \multicolumn{4}{|c|}{0.116893} \\
\hline Std. Error & \multicolumn{4}{|c|}{0.089883} & \multicolumn{4}{|c|}{0.034641} & \multicolumn{4}{|c|}{0.035467} \\
\hline $\mathbf{F}$ & \multicolumn{4}{|c|}{85.80900} & \multicolumn{4}{|c|}{238.6928} & \multicolumn{4}{|c|}{10.68478} \\
\hline$p$-value & \multicolumn{4}{|c|}{0.000000} & \multicolumn{4}{|c|}{0.000000} & \multicolumn{4}{|c|}{0.000000} \\
\hline
\end{tabular}

\section{Determining the appropriate panel model:}

Table 10. Wald, LM and Hausman tests

\begin{tabular}{cccccccc}
\hline \multicolumn{2}{c}{ Wald test } & \multicolumn{2}{c}{ LM (Lagrange Multiplier) test } & \multicolumn{2}{c}{ Hausman test } & \multicolumn{2}{c}{ Co-integration test (Kao test) } \\
\hline F & $p$-value & Breusch-Pagan & $p$-value & $\chi^{2}$ & $p$-value & t & $p$-value \\
\hline 131.6381 & 0.0000 & 2324.982 & 0.0000 & 26.894410 & 0.0002 & $\mathbf{- 3 . 0 0 6 7 8 7}$ & 0.0013 \\
\hline
\end{tabular}

d) Wald test (f test):

p-value $=0.000<\alpha=0.05$ which indicate that fixed effect model is better than the pooled OLS model.

e) Breusch pagan test statistic:

p-value $=0.000<\alpha=0.05$ which indicate that Random effect model is better than pooled OLS model. 
f) Hausman test statistic:

$\mathrm{p}$-value $=0.0002<\alpha=0.05$ which indicate that fixed effects model is better than random effect model.

Therefore, the best estimating model for panel regression to determine the relation between governance and human development is fixed effect model.

According to fixed effect model, the governance has a positive significant impact on human development.

Moreover, it found that these variables combined interpreted $93.5 \%$ of the changes in human development, while the remaining $6.5 \%$ can be attributed to other factors (not included in our study).

The value of adjusted $R^{2}(0.931205)$ is the same as $R^{2}(0.935123)$ which indicates that the high $R^{2}$ is not due to the increase in the number of independent variables but because of the importance of each variable in the model.

We can rely on the model in predicting the changes in human development as p-value $=0.000<\alpha=0.05$. Also, the value of the standard error of the estimate is very low (0.034641) which indicate the goodness of the model. There is no collinearity between the independent variables in the model as variance inflation factor (VIF) for each variable is less than 10 . Which indicate that the correlation between the variables didn't affect the regression model.

\section{Main findings in determining the impact of governance on Economic growth and Human Development:}

1) There is no relationship between governance and economic growth in MENA countries.

2) Only 5 countries out of 20 countries show little relationship in one or more indicators of governance (Algeria, Sudan, Iraq, Djibouti and Syria).

3) The indicator of governance that affect economic growth in Algeria is political stability.

4) The indicators of governance that affect the economic growth in Sudan is government effectiveness.

5) The indicators of governance that affect the economic growth in Iraq is the Government Effectiveness, Regulatory Quality and Rule of Law.

6) The indicators of governance that affect economic growth in Djibouti is voice and accountability.

7) The indicator of governance that affect economic growth in Syria is government effectiveness.

8) No impact of the global financial crisis in 2008 on the relationship between governance and economic growth in all study countries except the United Arab Emirates, Iraq.

9) The most countries ( 3 out of 5 countries) that have a relationship between the indicators of governance and economic growth are countries that are at the low level of human development.

10) There is significant relationship between governance and human development.

\section{Conclusion}

This paper attempts to answer four questions: - to what extent governance affect economic growth in MENA whether the financial crisis affects the relationship between governance and economic growth - does the relationship between governance and economic growth vary from country to country based on each country's level of development - to what extent governance affect human development in MENA countries.

To examine these questions, we used data of 20 countries during the period (1996-2017) we used panel data (longitudinal data) by applying the three longitudinal models: pooled regression model, fixed effect model and Random effect model.

The results illustrates that there is no relationship between governance and economic growth in MENA countries and no impact of the financial crisis on the relationship between governance and economic growth.

Also, the results illustrate that there is a significant relationship between governance and human development in MENA.

These results may be due to that most of MENA countries have achieved fragile levels of economic growth that doesn't depend on good governance. Which consider unsustainable economic growth that depends mainly on abundance of natural resources.

While in order to achieve better quality of life through enhance human development this will depend on existence of good governance.

Also, this paper found that most countries ( 3 out of 5 countries) that have a relationship between one or more indicators of governance and economic growth are countries that are at the low level of human development. 


\section{References}

Adnen, O., \& Mohamed, A. L. (2015). Growth, inequality and Governance: A case of MENA countries. SSRG International Journal of Economics \& Management Studies, 2(2).

Alesina, A., Sule, O., Nouriel, R., \& Phillip, S. (1996). Political instability and economic growth. Journal of Economic Growth, 1(2), 189-211. https://doi.org/10.1007/BF00138862

Alshehri, M., \& Drew, S. (2010). Implementation of e government: Advantages and challenges.

Bassam, A. B. (2013). The relationship between governance and economic growth during times of crisis. European Journal of Sustainable Development, 2(4), 1-18. https://doi.org/10.14207/ejsd.2013.v2n2p1

Bichaka, F., \& Christian, N. (2010). The impact of governance on Economic growth: Further evidence for Africa. Department of Economics and finance working paper series, Dec 2010.

Christiane, A., \& Charles, O. (2006). Uses and abuses of governance indicators. OECD, Development centre studies.

Colin, K. K. (2014). Assessing the impact of regulatory reform in developing countries. Public Administration and Development, 34, 162-168. https://doi.org/10.1002/pad.1693

Daniel, K., \& Aart, K. (2003). Governance and growth: Causality which way? Evidence for the world. World bank.

Daniel, K., \& Arat, K. (2002). Growth without governance. World bank.

Daniel, K., Aart, K., \& Massimo, M. (2010). The worldwide governance indicators: Methodology and analytical issues. World bank policy Research working paper no. 5430.

Dimirios, A., \& Simon, P. (2001). Political instability and economic growth: Uk time series evidence. Scottish Journal of Political Economy, 48(4). https://doi.org/10.1111/1467-9485.00205

Elisa, V., \& Sara, P. (2011). The impact of institutional quality on economic growth and development: An empirical study. Journal of Knowledge Management, Economics and Information Technology, 6.

Emin, A. K., \& Alpaslan, A. (2017). Political instability, corruption and economic growth: Evidence from a panel of OECD countries. Business and Economic Research Journal, 8(3), 363-377. https://doi.org/10.20409/berj.2017.55

Engjell, P. (2015). The impact of good governance in the economic development of western Balkan countries.

Erzsebet, N. R. et al. (2012). The Arab spring, its impact on the region and on the Middle East conference policy Brief no.9/10. Academic paper orchestra Middle East.

Glaeser et al. (2004). Do Institutions cause growth. NBER working paper series, June 2004. https://doi.org/10.3386/w10568

Hasan, V., \& Erdogan, T. (2017). Crisis, institutional quality and economic growth.

IFES. (2017). Democracy and Governance in the Middle East and North Africa. International Foundation for Electoral Systems.

Jeff, H., \& Anwar, S. (1998). Applying a simple measure of good governance to the debate on fiscal decentralization. World bank.

Laura, El K., Bassam, F., \& Richard, M. (2014). The Arab uprising and MENA political Instability: Implications for oil \& Gas Markets. OIES paper: MEP8.

Louis, A., \& Deval, D. (2013). Overview on the Rule of law and sustainable Development for the global dialogue on Rule of law and the past 2015 Development Agenda, Background paper.

Mahmoud, A. B. (2012). Governance and growth in MENA region evidence from panel data analysis. International Research Journal of Finance and Economics, 98.

Marie, H. (2010). Institutional quality and economic growth- a comparison across development stages. Bachelor thesis, Lund university.

Md Rafayat, A., Erick, K., \& Bizuayehu, B. (2017). Government effectiveness and economic growth. Economics Bulletin, 37(1), 222-227.

Nasser, s., \& Hala, Y. (2003). E- government: Technology for good governance, Development and Democracy in the MENA countries. ERF working paper (0304). 
OECD. (2013). Issue paper on corruption and Economic growth. OECD.

Paitoon, K. (2018). Good governance and economic growth: An investigation of thailand and selected Asian countries. Eurasian Journal of Economics and Finance, 6(1), 93-106. https://doi.org/10.15604/ejef.2018.06.01.009

Rachid, M., \& Ahmed, H. (2017). Good governance and economic growth: A contribution to the Institutional debate and state failure in Middle East and North Africa. Asian Journal of Middle Eastern and Islamic Studies, 11(3), 107-120. https://doi.org/10.1080/25765949.2017.12023313

Rodrik. (2008). Thinking about governance, in the world bank in governance, growth and development decision making, 2008.

Salih, T., \& Ali, A. (2016). Economic and political factors affecting corruption in developing countries. International J. Eco. Res., 711, 120-136.

Tammie, O. N., Marta, F., \& Alan, H. (2007). Evaluation of citizen's voice \& Accountability. Review of the Literature \& Donor Approaches Report.

Thomas, M. A. (2010). What do the worldwide governance indicators measure? The European Journal of Development Research, 22(1). https://doi.org/10.1057/ejdr.2009.32

UNDP. (2010). Voice and accountability for improved service delivery. Background paper, UNDP Regional centre in Cairo.

United Nation. (2007). Public Governance Indicators: A literature Review. Department of Economic and social Affairs.

World Bank. (2003). Better Governance for development in the Middle East and North Africa. MENA Development Report 27146.

Xuehul, H., Haider, K., \& Juzhong, Z. (2014). Do governance indicators explain development performance? A cross country analysis. ADB Economics working paper series no 417.

\section{Copyrights}

Copyright for this article is retained by the author(s), with first publication rights granted to the journal.

This is an open-access article distributed under the terms and conditions of the Creative Commons Attribution license (http://creativecommons.org/licenses/by/4.0/). 